\title{
NEBIVOLOL INDUCED HYPERKALEMIA: CASE REPORT
}

\author{
Karmela Altabas, Velimir Altabas and Tonko Gulin \\ Clinical Department of Internal Medicine, Sestre milosrdnice University Hospital Center, Zagreb, Croatia
}

\begin{abstract}
SUMMARY - In this article, we document a conclusive case of nebivolol-induced hyperkalemia for the first time in the known medical literature. Hyperkalemia is associated with serious conditions such as cardiac arrhythmias and sudden cardiac death. Nebivolol was not known to cause hyperkalemia, and this event is not listed in its summary of product characteristics (SmPC). For older beta blockers, hyperkalemia is recognized as a rare adverse event linked to cytochrome P450 2D6 (CYP2D6) polymorphism and poor drug degradation. Our patient, a 47-year-old woman taking nebivolol for hypertension developed persistent hyperkalemia, with serum potassium levels up to $6.4 \mathrm{mmol} / \mathrm{L}$. After extensive diagnostic evaluation and exclusion of other known conditions leading to hyperkalemia, its cause remained occult. Since hyperkalemia coincided with increased doses of nebivolol, dose reduction and discontinuation were attempted, resulting in normalized serum potassium. Poor drug metabolism could not explain this adverse effect, since pharmacogenetic testing showed no relevant aberrations. In conclusion, hyperkalemia is a harmful adverse event with possible lethal outcome, and it may be caused by nebivolol. Therefore, medical professionals have to be aware of this side effect and hyperkalemia should be listed as an adverse event in nebivolol SmPC.
\end{abstract}

Key words: Nebivolol; Adverse event; Hyperkalemia

\section{Introduction}

Nebivolol is a third-generation beta blocking agent with high selectivity for beta- 1 adrenergic receptors ${ }^{1,2}$, used in the treatment of hypertension, heart failure and cardiac arrhythmias ${ }^{1,3-6}$. It reverses left ventricular remodeling, increases stroke volume, preserves cardiac output and improves diastolic dysfunction ${ }^{5}$. Its antihypertensive effect is due to reduced peripheral vascular resistance and vasodilatation resulting from facilitated release of nitric oxide ${ }^{1,7}$. Major adverse effects include headache, fatigue, dizziness, diarrhea, hyperlipoproteinemia, hyperuricemia and peripheral edema.

Hyperkalemia is not listed in nebivolol summary of product characteristics $(\mathrm{SmPC})^{8,9}$. However, mild hyperkalemia is known to be caused primarily by nonse-

Correspondence to: Velimir Altabas, $M D$, PhD, Clinical Department of Internal Medicine, Sestre milosrdnice University Hospital Center, Vinogradska c. 29, HR-10000 Zagreb, Croatia

E-mail: velimir.altabas@gmail.com

Received February 22, 2016, accepted April 4, 2016 lective beta blockers, but there are also some case reports of more cardioselective beta blocking agents such as atenolol and metoprolol causing hyperkale$\mathrm{mia}^{10-14}$. Although there is a report of nebivolol-related hyperkalemia to regulatory agencies (1 case in the open Food and Drug Administration database of adverse events in February 2016), there are still concerns about its causality. The information on this website relates to suspected side effects, i.e. medical events that were observed following the use of a medicine, but which were not necessarily related to or caused by the particular drug ${ }^{15}$.

There is still no conclusive evidence for nebivololinduced hyperkalemia in medical literature because case reports are lacking. There was a single assumption of nebivolol related hyperkalemia published in 2002, describing a case of an elderly patient with interfering comorbidities, but without definitive proof ${ }^{16}$.

The underlying mechanism of hyperkalemia related to beta blockers usually considered is reduced cellular potassium uptake due to decreased $\mathrm{Na}^{+} / \mathrm{K}^{+}$ 
ATPase pump activity ${ }^{12,17}$, suppressed catecholaminedependent renin release, and thereby diminished aldosterone synthesis ${ }^{10,18}$. Like many other adverse effects of beta blockers, hyperkalemia was linked to poor drug degradation due to cytochrome P450 2D6 (CYP2D6) polymorphism and increased drug bioavailability. Particularly for nebivolol, the bioavailability of orally taken drug is $12 \%$ on average in patients with extensive metabolism, in comparison to $96 \%$ in poor metabolizers. Peak concentration of nebivolol in plasma of persons with poor metabolism is up to 23 times higher than in those with extensive metabolism ${ }^{19-21}$, increasing the possibility of adverse events. However, it seems that nebivolol is metabolized through different pathways in extensive and poor metabolizers, resulting in a higher concentration of active metabolites in extensive metabolizers, but without clinical significance. Despite major differences in drug disposition, the clinical response was similar between extensive and poor metabolizers, likely as a result of active hydroxylated metabolites produced in extensive metabolizers ${ }^{21}$.

\section{Case Report}

We present a case of a 47-year-old woman taking nebivolol for hypertension, who developed severe persistent hyperkalemia. Her medical history included hemorrhagic stroke 22 years before, recurrent kidney stones, and chronic cystitis. Hypertension was diagnosed four years before and she began treatment with nebivolol $2.5 \mathrm{mg}$ qd. Initially, blood pressure was well controlled. All relevant laboratory findings including serum electrolytes were within the normal range. After one year, the dose of nebivolol was raised to $5 \mathrm{mg}$ qd due to poorly controlled blood pressure. Within weeks, an increase in serum potassium up to $6.4 \mathrm{mmol} / \mathrm{L}$ (reference range: $3.9-5.1 \mathrm{mmol} / \mathrm{L}$ ) was noticed, with still not well-controlled hypertension $(145 / 85 \mathrm{~mm} \mathrm{Hg})$. The patient was advised to take a low potassium diet and treatment with indapamide $2.5 \mathrm{mg}$ qd was started. After failing to correct potassium levels, furosemide 40 $\mathrm{mg}$ biw was added, but hyperkalemia and non-controlled hypertension persisted. At the time, she was complaining of chronic fatigue and lack of appetite, resulting in $2-\mathrm{kg}$ weight loss over 2 months. Her physical examination showed discrete pretibial edema.

Her basic hematologic and metabolic panel revealed a serum potassium level of $5.5 \mathrm{mmol} / \mathrm{L}$, but other relevant blood findings were normal. Urine specific gravity, creatinine clearance, and potassium excretion in 24-h urine were within the reference range, while calcium and phosphate excretion was slightly reduced. Urinary albumin level and protein electrophoresis showed no abnormalities. Urine sediment analysis showed no relevant finding.

Ultrasound revealed normal renal and suprarenal morphology.

Hormonal evaluation excluded endocrine causes of hyperkalemia, with serum aldosterone, urinary $24-\mathrm{h}$ aldosterone, plasma cortisol, urinary $24-\mathrm{h}$ cortisol, corticotropin, basal plasma renin, renin after stimulation with furosemide and thyrotropin levels within the reference ranges.

She was taking no other drugs and did not suffer from diseases and states leading to massive cell destruction such as rhabdomyolysis, tissue necrosis, or burns. Pseudohyperkalemia was ruled out by well controlled venipuncture and repeated blood sampling.

Since the occurrence of hyperkalemia coincided with the nebivolol dose increase, dose reduction to 2.5 $\mathrm{mg}$ nebivolol qd was attempted, resulting promptly in normalized serum potassium. Nebivolol was discontinued and serum potassium level remained within the normal range.

After considering several therapeutic options, perindopril $2 \mathrm{mg}$ qd and indapamide $0.625 \mathrm{mg}$ qd were introduced. Blood pressure normalized at $135 / 80 \mathrm{~mm}$ $\mathrm{Hg}$ and peripheral pulse was $80 \mathrm{bpm}$. Fatigue and pretibial edema disappeared.

Variations of potassium concentration and blood pressure due to different antihypertensive drugs are shown in Table 1.

Although hyperkalemia is not listed in the nebivolol SmPC, in this patient hyperkalemia was an adverse effect of nebivolol, as a sequence of the events revealed. This conclusion could be supported by using specific tools such as Naranjo Adverse Drug Reaction Probability Score and the World Health Organization Uppsala Monitoring Centre Probability Scale ${ }^{22,23}$. Since hyperkalemia was serious and manifested with symptoms, additional pharmacogenetic testing focused on CYP2D6 polymorphism was performed. It showed the patient to be an extensive metabolizer of beta blocking agents, with both alleles of the wild type, so poor metabolism and abnormal pharmacokinetics could not explain the occurrence of hyperkalemia in this patient. 
Table 1. Time course of potassium concentration, therapeutic attempts and blood pressure

\begin{tabular}{|c|c|c|c|c|c|c|c|}
\hline Therapy & $\begin{array}{l}\text { Previous } \\
\text { therapy }\end{array}$ & $\begin{array}{l}\text { Nebivolol } \\
5 \mathrm{mg} \text { qd }\end{array}$ & $\begin{array}{c}\text { Nebivolol } 5 \mathrm{mg} \text { qd } \\
+ \\
\text { indapamide } \\
1.5 \mathrm{mg} \mathrm{qd}+ \\
\text { furosemide } \\
40 \mathrm{mg} \text { biw }\end{array}$ & $\begin{array}{l}\text { Nebivolol } \\
2.5 \mathrm{mg} \text { qd + } \\
\text { moxonidine } \\
0.4 \mathrm{mg} \text { qd }\end{array}$ & $\begin{array}{l}\text { Moxonidine } \\
0.6 \mathrm{mg} \text { qd }\end{array}$ & $\begin{array}{c}\text { Verapamil } \\
240 \mathrm{mg} \text { qd }+ \\
\text { moxonidine } \\
0.4 \mathrm{mg} \text { qd }+ \\
\text { indapamide } \\
1.5 \mathrm{mg} \text { qd }\end{array}$ & $\begin{array}{l}\text { Perindopril } \\
2 \mathrm{mg} \mathrm{qd}+ \\
\text { indapamide } \\
0.625 \mathrm{mg} \mathrm{qd}\end{array}$ \\
\hline $\begin{array}{l}\text { Potassium } \\
(\mathrm{mmol} / \mathrm{L})\end{array}$ & 3.9 & 6.4 & 5.5 & 4.5 & 4.8 & 4.8 & 3.8 \\
\hline $\begin{array}{l}\text { Blood } \\
\text { pressure } \\
(\mathrm{mm} \mathrm{Hg})\end{array}$ & $150 / 100$ & $140 / 90$ & $150 / 85$ & $145 / 85$ & $160 / 80$ & $160 / 80$ & $135 / 80$ \\
\hline
\end{tabular}

\section{Discussion and Conclusion}

Hyperkalemia is a known side effect of several older beta blockers including nonselective and some selective members of the class. The occurrence of hyperkalemia with these drugs was thought to be linked to poor metabolism due to CYP2D6 polymorphism.

There is still no conclusive report of hyperkalemia induced by nebivolol therapy in the literature up to now. Although hyperkalemia is not recognized as a side effect of nebivolol therapy, it seems that nebivolol is capable to cause significant hyperkalemia.

In the patient described in this article, hyperkalemia was a side effect of nebivolol. This conclusion is based on the sequence of events, exclusion of other possible causes of hyperkalemia, and supported by laboratory findings.

Causal relationship of drug related hyperkalemia has been confirmed as definitive/certain according to Naranjo Adverse Drug Reaction Probability Score of 9 and the World Health Organization Uppsala Monitoring Centre Probability Scale ${ }^{22,23}$.

The severity of hyperkalemia did not correlate with its antihypertensive effect, it occurred at a higher drug dose, and appeared to be reversible after drug discontinuation. Because of the risks associated with hyperkalemia, re-challenge was not performed. Interestingly, additional pharmacogenetic testing did not explain the occurrence of this side effect, since the patient was found to be extensive metabolizer of beta blocking agents. In fact, if she were poor metabolizer due to CYP2D6 polymorphism, the potential accumulation of the drug would have surely resulted in a more profound blood pressure reduction.
A reasonable genetic explanation for hyperkalemia could be found in $\beta_{1}$ and $\beta_{2}$ adrenoreceptor (ADRB1 and ADRB2) polymorphism, but data linking adverse effects of beta blockers to these genetic variants are still very rare and limited, not allowing any definite conclusion at this time ${ }^{24}$.

Finally and most importantly, hyperkalemia as a harmful adverse event must be listed as an adverse event in the nebivolol SmPC.

\section{References}

1. Münzel T, Gori T. Nebivolol: the somewhat-different betaadrenergic receptor blocker. J Am Coll Cardiol. 2009 Oct 13; 54(16):1491-9.

2. Bundkirchen A, Brixius K, Bölck B, Nguyen Q, Schwinger RH. Beta 1-adrenoceptor selectivity of nebivolol and bisoprolol. A comparison of [3H]CGP 12.177 and [125I]iodocyanopindolol binding studies. Eur J Pharmacol. 2003 Jan 26;460(1):19-26.

3. Hilas O, Ezzo D. Nebivolol (Bystolic), a novel beta blocker for hypertension P T. 2009 April;34(4):188-92.

4. Dery AS, Hamilton LA, Starr JA. Nebivolol for the treatment of heart failure. Am J Health Syst Pharm. 2011 May 15; 68(10):879-86.

5. Howlett JG. Nebivolol: vasodilator properties and evidence for relevance in treatment of cardiovascular disease. Can J Cardiol. 2014 May;30(5 Suppl):S29-37.

6. Wyse DG. Pharmacotherapy for rhythm management in elderly patients with atrial fibrillation. J Interv Card Electrophysiol. 2009 Jun;25(1):25-9.

7. Toblli JE, DiGennaro F, Giani JF, Dominici FP. Nebivolol: impact on cardiac and endothelial function and clinical utility. Vasc Health Risk Manag. 2012;8:151-60.

8. U.S. Food and Drug Administration. Bystolic - highlights of prescribing information [Internet] Washington (US): FDA 
(US); 2011. Available from: http://www.accessdata.fda.gov/ drugsatfda_docs/label/2011/021742s013lbl.pdf (revised 2011 December, accessed 25 January 2015).

9. Drugsite Trust (NZ), Nebivolol side effects [Internet]. Auckland (NZ): Drugs.com. 2008 (revised 2008 August, accessed 25 January 2015). Available from: http://www.drugs.com/sfx/ nebivolol-side-effects.html

10. Ben Salem C, Badreddine A, Fathallah N, Slim R, Hmouda H. Drug-induced hyperkalemia. Drug Saf. 2014 Sep;37(9): 677-92.

11. Liamis G, Milionis H, Elisaf M. Blood pressure drug therapy and electrolyte disturbances. Int J Clin Pract. 2008 Oct;62 (10):1572-80.

12. Sica DA. Antihypertensive therapy and its effects on potassium homeostasis. J Clin Hypertens (Greenwich). 2006 Jan;8(1): 67-73.

13. Beliaev AM, Smith W. Metoprolol-induced hyperkalaemia in chronic respiratory acidosis. N Z Med J. 2007 Jun 29;120 (1257):U2620.

14. Kassem H, Hajjar C, El Gharbi T, Turner L. Hyperkalemia induced by atenolol. Rev Med Interne. 2009 Aug;30(8):714-6. doi: 10.1016/j.revmed.2008.10.011. Epub 2008 Nov 18.

15. U.S. Food and Drug Administration. [Internet]. Silver Spring, USA. (accessed 13 February 2016). Available from: https:// open.fda.gov/drug/event/

16. Self assessment answers: Hyperkalaemia in an elderly diabetic patient. Postgrad Med J. 2002;78:57-60.
17. Clausen T. Hormonal and pharmacological modification of plasma potassium homeostasis. Fundam Clin Pharmacol. 2010 Oct;24(5):595-605.

18. Fung JW, Yu CM, Yip G, Chan S, Yandle TG, Richards AM, et al. Effect of beta blockade (carvedilol or metoprolol) on activation of the renin-angiotensin-aldosterone system and natriuretic peptides in chronic heart failure. Am J Cardiol.2003 Aug 15;92(4):406-10.

19. Weiss R. Nebivolol: a novel beta-blocker with nitric oxide-induced vasodilatation. Vasc Health Risk Manag. Sep 2006;2(3): 303-8.

20. Sahana GN, Sarala N, Kumar TN. Nebivolol - pharmacological aspects. Int J Biol Med Res. 2011;2(2):577-80.

21. Lefebvre J, Poirier L, Poirier P, Turgeon J, Lacourciere Y. The influence of CYP2D6 phenotype on the clinical response of nebivolol in patients with essential hypertension. $\mathrm{Br} \mathrm{J}$ Clin Pharmacol. 2007 May;63(5):575-82.

22. Naranjo CA, Busto U, Sellers EM, Sandor P, Ruiz I, Roberts EA, et al. A method for estimating the probability of adverse drug reactions. Clin Pharmacol Ther. 1981;30:239-45.

23. Uppsala Monitoring Centre (Internet), Uppsala. The use of the WHO-UMC system for standardised case causality assessment. (cited 2014 October 1). Available from: http//www.whoumc.org/Graphics/24734.pdf

24. Baudhuin LM, Miller WL, Train L, Bryant S, Hartman KA, Phelps M, et al. Relation of ADRB1, CYP2D6, and UGT1A1 polymorphisms with dose of, and response to, carvedilol or metoprolol therapy in patients with chronic heart failure. Am J Cardiol. 2010 Aug 1;106(3):402-8.

Sažetak

\section{HIPERKALIJEMIJA IZAZVANA NEBIVOLOLOM: PRIKAZ SLUČAJA}

\section{K. Altabas, V. Altabas i T. Gulin}

U ovom članku je po prvi put u poznatoj medicinskoj literaturi dokumentiran slučaj hiperkalijemije izazvane nebivololom. Hiperkalijemija je povezana s ozbiljnim stanjima kao što su srčane aritmije i iznenadna srčana smrt. Za nebivolol dosad nije bilo poznato da može uzrokovati hiperkalijemiju pa ona nije navedena u sažetku opisa svojstava lijeka. Za starije beta blokatore hiperkalijemija je poznata kao rijetka nuspojava lijeka vezana uz polimorfizam citokroma P450 2D6 (CYP2D6) i slabiju razgradnju lijeka. Nebivolol je uzimala i naša 47-godišnja bolesnica zbog hipertenzije, s posljedičnim razvojem refraktorne hiperkalijemije, s razinama serumskog kalija do $6,4 \mathrm{mmol} / \mathrm{L}$. Nakon opsežne dijagnostičke evaluacije i isključenja drugih poznatih uvjeta koji dovode do hiperkalijemije njen uzrok nije razjašnjen. Pojava hiperkalijemije se podudarala s povećanjem doze nebivolola, a smanjenje doze i prekid terapije doveli su do normalizacije serumskog kalija. Ova nuspojava nije se mogla objasniti usporenim metabolizmom lijeka budući da farmakogenetičko testiranje nije pokazalo relevantnih aberacija. U zaključku napominjemo da je hiperkalijemija štetan događaj s mogućim smrtnim ishodom koja može biti uzrokovana nebivololom. Stoga liječnici moraju biti svjesni ove nuspojave i hiperkalijemija treba biti navedena kao moguća nuspojava u sažetku opisa svojstava ovoga lijeka.

Ključne riječi: Nebivolol; Štetan događaj; Hiperkalijemija 